Winter 1998

\title{
Interactive Effects of Parents' Trait Verbal Aggressiveness and Situational Frustration on Parents' Self-Reported Anger
}

\author{
Jill E. Rudd \\ Cleveland State University, J.RUDD@csuohio.edu \\ Sally Vogl-Bauer \\ Jean A. Dobos \\ Michael J. Beatty \\ Kristin M. Valencic
}

Follow this and additional works at: https://engagedscholarship.csuohio.edu/clcom_facpub

Part of the International and Intercultural Communication Commons

How does access to this work benefit you? Let us know!

\section{Publisher's Statement}

This is an Accepted Manuscript of an article published by Taylor \& Francis in Communication Quarterly in Winter 1998, available online: http://www.tandfonline.com/10.1080/ 01463379809370080.

\section{Recommended Citation}

Rudd, Jill E.; Vogl-Bauer, Sally; Dobos, Jean A.; Beatty, Michael J.; and Valencic, Kristin M., "Interactive Effects of Parents' Trait Verbal Aggressiveness and Situational Frustration on Parents' Self-Reported Anger" (1998). Communication Faculty Publications. 56.

https://engagedscholarship.csuohio.edu/clcom_facpub/56

This Article is brought to you for free and open access by the School of Communication at EngagedScholarship@CSU. It has been accepted for inclusion in Communication Faculty Publications by an authorized administrator of EngagedScholarship@CSU. For more information, please contact library.es@csuohio.edu. 


\section{Interactive Effects of Parents' \\ Trait Verbal Aggressiveness and \\ Situational Frustration on Parents' \\ Self-Reported Anger}

Jill E. Rudd, Sally Vogl-Bauer, Jean A. Dobos, Michael J. Beatty, and Kristin Marie Valencic

T $\mathrm{n}$ the past five years, a steady stream of studies has focused on the central role of parent trait verbal aggressiveness in the child-rearing context (Bayer \& Cegala, 1992; Beatty, Burant, Dobos, \& Rudd, 1996; Beatty, Zelley, Dobos, \& Rudd, 1994; Infante, in press; Rudd, Beatty, Vogl-Bauer, \& Dobos, in press). Bayer and Cegala (1992), for example, found that parents who embrace authoritarian parenting 
philosophies are more likely to be high in trait verbal aggressiveness than are democratic parents. Beatty et al. (1994) reported a strong positive relationship between adult sons' perceptions of sarcasm and criticism from fathers and their fathers' self-reported trait verbal aggressiveness. This particular finding is important because other studies have shown that sarcasm and criticism from fathers have negative effects on sons' social relationships and personal development (Beatty \& Dobos, 1992a, 1992b, 1993a, 1993b, 1993c). Recent studies, have shown that fathers' trait verbal aggressiveness is negatively correlated with the appropriateness and effectiveness of their plans for interacting with noncompliant sons (Beatty, Burant, Dobos, \& Rudd, 1996; Rudd, et al., in press).

Although Infante (1987a) conceptualized trait verbal aggressiveness as a subset of hostility, which represents the broad tendency to be angry, researchers have not yet established an empirical link between trait verbal aggressiveness and the experience of anger during interaction. Such a link is potentially significant considering the widespread documentation of anger as a common parental experience (Bjorkqvist \& Osterman, 1992; Cummings, Vogel, Cummings, \& El-Sheikh, 1989; El-Sheikh, Cummings, \& Goetsch, 1989; Epps \& Kendall, 1995; Fatout, 1990). The purpose of the present study was to examine the relationship between parents' trait verbal aggressiveness and the anger experienced when interacting with their children. Specifically, we (a) administered a measure of trait verbal aggressiveness to parents, (b) solicited from parents written accounts of recent incidents involving conflicts with their children, and (c) administered a measure of anger referring to the incident.

\section{Trait Verbal Aggressiveness}

In his initial work, Infante (1987a) advanced a personality-based conceptualization of verbal aggressiveness. One of the major defining characteristics of verbal aggressiveness is that it constitutes a predisposition or tendency to engage in aggressive symbolic action. Indeed, published studies indicate that in contrast to persons low in the trait, communicators high in trait verbal aggressiveness plan to send and report sending more aggressive messages (e.g. Beatty, et al., 1996; Infante, Riddle, Horvath, \& Tumlin, 1992; Infante, Sabourin, Rudd, \& Shannon, 1990). A second defining feature of verbal aggressiveness is intent to inflict psychological pain or harm (Infante, 1987a; Infante \& Wigley, 1986). Although verbal aggression sometimes produces constructive outcomes, its consequences in interpersonal relationships are "almost always destructive" (Infante, 1987a, p. 165). The long list of psychological harms inflicted by verbal aggression includes embarrassment, feelings of inadequacy, humiliation, hopelessness, despair and depression (Infante, 1987a).

\section{Trait Verbal Aggressiveness and Anger During Interaction}

While some scholars have emphasized the ways anger is communicated (e.g. Canary, Spitzberg, \& Semic, in press), it is also important to understand the subjective experience of anger during interpersonal interaction. Within the context of parentchild interaction, parents' experiences of anger are important not only because of the potential for violence, but also because the internal experience of anger has long-term relational implications. First, affective experiences, both positive and negative, contribute to relational history, which scholars recognize as an important dynamic in family communication (Vangelisti, 1993). Second, frequent and intense anger 
experiences when interacting with children are likely to influence parents' expected outcomes about future interactions. As such, anticipated anger-provoking interactions often short circuit analytical processes, leading to hostile reactions (Infante, 1987a).

\section{Interactionist Perspective}

Generally speaking, trait-oriented communication scholars have worked from one of three paradigms when conceptualizing the influence of traits on state reactions, whether these reactions are cognitive, affective, or behavioral in nature. In a recent summary of the literature, Beatty (in press) described these three paradigms. One perspective, described by Beatty, which Infante, Rancer, and Womack (1997) refer to as the trait position, holds that communicative behavior in a particular situation is solely due to a single broad predisposition. According to this perspective, parent anger would be seen as principally the function of a single trait such as generalized hostility or trait verbal aggressiveness.

A second approach, which Beatty (in press) labels the multiple trait perspective, treats state responses as joint products of more than one trait (e.g., trait verbal aggressiveness and trait argumentativeness). Scholars working from this paradigm recognize that at times, traits counteract other traits (e.g., communication apprehension versus need for achievement in a public speaking class), whereas at other times, the effects of multiple traits are additive or even synergistic in the production of responses (e.g., high trait verbal aggressiveness and low trait argumentativeness).

The third paradigm, known as the interactionist position (Infante, Rancer, \& Womack, 1997), suggests that trait and situational variables interact to produce measurable responses in a particular context. Foundational to this approach is the assumption that neither traits nor situations alone account for state reactions. According to interactionists, traits represent individual differences in degrees of sensitivity to classes of stimuli.

Although all three paradigms are represented in the communication literature (Beatty, in press), the interactionist position is most clearly evident in the scholarly work focussed on trait verbal aggressiveness (Infante, 1987a, 1987b; Infante, Rancer, \& Womack, 1997). Infante's (1987a, 1987b) theorizing about the interaction between situational factors and trait verbal aggressiveness was heavily influenced by Berkowitz' (1962) conceptualization of the aggressive personality. According to Berkowitz (1962), the notion of an aggressive personality does not imply incessant aggressive behavior. Rather, hostile responses are simply more easily stimulated in such individuals. Following this thinking, Infante (Infante, 1987a, 1987b, Infante \& Rancer, 1996; Infante \& Wigley, 1986) argued that trait verbal aggressiveness does not represent a chronic condition. Instead, it represents a predisposition to engage in aggressive symbolic action "which is latent until anger is aroused" (Infante, 1987, p. 178).

\section{Frustration As A Situational Stimulant}

Under Infante's scheme, frustration functions as a stimulant of anger. In particular, "anger is aroused when someone or something is categorized as frustrating according to the relevant cues and stimuli in the situation" (Infante, 1987a, p.178). Important to our study, interacting with young children can be a source of frustration 
for parents. In particular, family communication scholars have noted that the noncompliance of children is among the most frustrating experiences parents encounter on a regular basis (Stafford \& Bayer, 1993). Indeed, as scholars have observed, unsuccessful attempts to get children to do something or to stop doing something introduce frustration into the parenting context. Based on the preceding discussion, it seems reasonable to expect the relationship between trait verbal aggressiveness and anger to depend on the amount of frustration stimulated by children's noncompliance. For example, during highly frustrating interaction, anger should be more strongly stimulated in parents high in trait verbal aggressiveness than in parents who are lower in the trait. However, we also expect that less anger will be stimulated in parents high in trait verbal aggressiveness when interactions are less frustrating. Thus, we propose that parents' anger in response to noncompliant children is most accurately described as a magnitude or ordinal interaction between parents' trait verbal aggressiveness and the degree of frustration experienced during the interaction.

\section{METHOD}

\section{Measures}

Infante and Wigley's (1986) twenty item measure of trait verbal aggressiveness was used in the present study. Previous research has established the validity and reliability of the measure (Infante, Chandler \& Rudd, 1989; Infante, et al., 1990; Infante \& Gorden, 1985). In the present study the alpha reliability for the measure was .79. Parents' frustration was assessed using four items referring to how they felt during the interaction with their children. The items were: frustrated; baffled; perplexed; and thwarted. Patterned after Speilberger, Gorsuch, and Luschene's (1969) response options for measuring the intensity of emotional states, the response options for each item were: not at all; somewhat; moderately; and very much. The alpha reliability coefficient for this scale was .73.

Parent anger regarding the interaction with their children was measured using a format identical to that described for frustration, except the items were: angry; furious; hostile; and mad. The alpha reliability coefficient for this scale was .81 .

\section{Procedure}

A total of 93 parents participated in this study (25 fathers and 68 mothers). Ten fathers and sixteen mothers were single parents, while 15 fathers and 51 mothers were married (One mother did not provide marital status data). Parents' age ranged from 20 to 49 , with a mean age of $34.35(s d=6.76)$. The ethnic breakdown of parents was $75.6 \%$ Caucasian, $16.7 \%$ African-American, and the remaining $7.7 \%$ consisted of Hispanics, Native Americans, Asians, or other ethnic groups. With respect to educational level, $16.7 \%$ of the parents had a high school education, $43.3 \%$ had some college education, $21.1 \%$ had a college degree, and $18.9 \%$ had at least some graduate education. Participants with gross family incomes less than $\$ 20,000$ numbered $26.7 \%$ of the households sampled. Forty-two percent of the participants family incomes ranged from $\$ 20,000$ to $\$ 50,000$, and $31.1 \%$ had gross family incomes greater than $\$ 50,000$ (the median gross family income was between $\$ 30,000$ and $\$ 40,000$ ). Fortyfour male and forty-nine female children served as references for parents' reports. Approximately $94 \%$ of the children were between the ages of 1 to 12 (mean age $=7.24$, $s d=4.13$ ).

Parents provided written descriptions of a recent interaction in which they failed 
in their efforts to get their children to do something or cease doing something. Eightyseven participants were able to recall an example of such an interaction within the previous week and five participants were able to generate an example that occurred within ten days prior to the data collection. One participant, who was subsequently deleted, reported that her child always complied upon request. Descriptions of interactions depicted a variety of issues with typical examples including appropriate table manners and eating behaviors, observing bedtime, hitting and bickering with siblings, doing homework, cleaning up their rooms, making annoying noises and interrupting parents' conversations with other adults.

\section{RESULTS}

Means and standard deviations for all variables are reported in Table 1. Overall, the results supported the hypothesis.

TABLE 1

Means and Standard Deviations for All Variables

\begin{tabular}{lrc}
\hline Variables & $\mathrm{M}$ & sd \\
\hline Trait Verbal Aggressiveness & 43.26 & 8.88 \\
Frustration & 8.32 & 2.98 \\
Anger & 7.35 & 3.03 \\
$n=92$. & & \\
\hline
\end{tabular}

Because the predictors and dependent variables in the present study were all continuous variables, the hypothesis was tested using multiple regression analysis in which trait verbal aggressiveness scores $\left(X_{1}\right)$, frustration scores $\left(X_{2}\right)$, and a multiplicative interaction term $\left(X_{1} X_{2}\right)$, were used to predict parent anger $(Y)$. The full model accounted for 33.93 percent of the variance in parent anger scores $(M R=.58, F$ $=15.06, d f=3 / 88, p<.01)$. Although main effects for trait verbal aggressiveness $(b=$ $.10, t=1.03, p=.31)$, and frustration $(b=.41, t=0.89, p=.38)$ were not statistically significant, the trait verbal aggressiveness $X$ frustration interaction was statistically significant $(b=.02, t=2.01, p<.05)$ as predicted.

TABLE 2

Summary of Statistical Associations Between Predictor Variables and Anger

\begin{tabular}{lcc}
\hline Predictor Variables & Measure of Association & Variance Explained \\
\hline Trait Verbal Aggressiveness $\left(\mathrm{X}_{1}\right)$ & $r=.25^{*}$ & .06 \\
Frustration $\left(\mathrm{X}_{2}\right)$ & $r=.50^{*}$ & .25 \\
Full Model $\left(\mathrm{X}_{1}+\mathrm{X}_{2}+\mathrm{X}_{1} \mathrm{X}_{2}\right)$ & $M R=.58^{*}$ & .34 \\
\hline
\end{tabular}

* $p<.05, n=92$.

Given the significant interaction coefficient detected for the multiplicative interaction term, it was necessary to determine whether the interaction was disordinal or ordinal as hypothesized. Following Kerlinger and Pedhazur's (1973) recommended 
procedure, we (1) regressed parent anger scores on trait verbal aggressiveness scores separately for parents reporting highly frustrating interactions and for those reporting only mildly frustrating interactions, and (2) determined the point of intersection for the two regression lines.

Although the sample can be split in a variety of ways when conducting such an analysis (e.g., median split, quartiles), we used standard deviation cut-offs (As indicated below, this criterion resulted in a clean separation along the lines of frustration, permitting a clear picture of the nature of the interaction). Specifically, parents whose frustration scores were at least one standard deviation above the mean were categorized as the highly frustrated group $(n=27)$ whereas those whose scores were one standard deviation below the mean were considered the mildly frustrated group $(n=21)$. A $t$-test indicated that the mean frustration score $(M=12.00, s d=1.21)$ for parents classified as engaged in highly frustrating interactions and the mean $(M=4.62, s d=0.50)$ for the mildly frustrated group were statistically different $(t=26.25$, $d f=47, p<.01)$. Furthermore, the mean difference for the two groups was twice the value for a large effect $(d=2.0)$ set by Cohen (1988). Overall these analyses indicated that the definitions of "highly" and "mildly" frustrating interactions provided clear separation of the two groups.

The point of intersection for the two regression lines was calculated according to the formula: $a_{1}-a_{2} / b_{2}-b 1$, where $a_{1}$ and $a 2$ represent the intercepts and $b_{1}$ and $b_{2}$ represent the regression coefficients for the two separate regression equations (Kerlinger \& Pedhazur 1973, p. 247). In this case, the point of intersection resulting from applying the formula to the parameters calculated by regressing anger on trait verbal aggressiveness for "mildly" frustrated parents $\left(a_{1}=2.44, b_{1}=.065\right)$ and "highly" frustrated parents $\left(a_{2}=-.018, b_{2}=.211\right)$ was 16.83 . Interactions are ordinal when the point of intersection falls outside the range of interest of the researchers, which can be defined within the score range on a variable. Since the point of intersection estimated in the present study falls beyond the maximum score for the frustration measure $(X=16.00)$, the point of intersection for the present data falls outside any possible range of interest. Thus, the interaction indicated by the significant interaction coefficient is clearly ordinal in nature, a finding that fully supports the hypothesized relationships among trait verbal aggressiveness, situational frustration, and parent anger.

\section{DISCUSSION}

The findings of the present study indicated that parents' trait verbal aggressiveness and frustration levels experienced during interactions with their children interact to produce their subjective anger states regarding those interactions: Trait verbal aggressiveness is more strongly related to anger under highly frustrating conditions than under mildly frustrating conditions. These results provide strong support for Infante's (1987a; Infante \& Rancer, 1996) theoretical stance presented earlier regarding anger as a product of trait verbal aggressiveness. Although the interaction of trait verbal aggressiveness and induced frustration in the production of anger constitutes an important proposition in Infante's work on the construct, empirical confirmation was not evident in the literature. Researchers had established that escalation of aggression is more likely when interactants' interaction goals are blocked (Beatty, et al., 1996; deTurck, 1987; Harris, Gergen, \& Lannamann, 1986; Infante, et al., 1989; Infante, et al., 1990; Infante, Trebing, Sheperd, \& Seed, 1984; Lim, 1990; Rudd, et al., in press) and that fathers high in trait verbal aggressiveness include 
more violent tactics in their plans for interacting with disobedient children than do fathers who are less verbally aggressive (Beatty, et al., 1996; Rudd, et al., in press). However, aggressive behavior and subjectively experienced anger are conceptually distinct. While anger often precedes aggression, scholars have noted that aggression often occurs in absence of anger and anger often occurs without aggression (Geen, 1990). Thus, the findings of the present study provides direct evidence for Infante's theorizing regarding anger as a product of both trait verbal aggressiveness and situational frustration.

The observed interaction also means that the higher parents' trait verbal aggressiveness, the more readily frustration is converted to anger. In a revision of the frustration-aggression hypothesis, Berkowitz (1969) argued that frustration produces arousal, which may either fuel fight or flight tendencies. Anger results when the tendency to fight or aggress is stronger than the tendency to flee. Later, Berkowitz (1989) suggested that the arousal is experienced as negative affect or general unpleasantness. It may be that persons high in trait verbal aggressiveness are more likely to experience the arousal or negative affect produced by frustration as anger than are those lower in the trait. Certainly, this conclusion is consistent with the view of traits as predispositions to respond to classes of stimuli.

Combined with the tendency for parents high in trait verbal aggressiveness to engage is coercive disciplinary tactics (Bayer \& Cegala, 1992; Beatty, et al., 1996; Rudd, et al., in press), anger stimulated by children's noncompliance might be viewed as a potential intensifier of parental response. In recent years, temperament researchers (e.g., Chess \& Thomas, 1989) have begun to identify types of children based on inborn, neurobiologically-driven behavior patterns. One type of child, labeled the "difficult child" (Chess \& Thomas, 1989), tends to be more challenging to teachers as well as parents in a number of ways, including a tendency toward noncompliance. Research reviewed by Belsky and Vondra (1993) indicates that in general difficult children are more likely targets of parental abuse than are other children. In light of the present findings, future research should consider the possibility that difficult children are at even greater risk of abuse when parented by adults high in trait verbal aggressiveness.

Since children's self-assertiveness, independence and other processes associated with identity formation and the development of a sense of autonomy often bring them into opposition with parents' desires, the findings of the present study have implications for child development. According to our findings, children parented by adults who are high in trait verbal aggressiveness are more likely to encounter anger when engaged in assertive behavior. Scholars (e.g., Geen, 1990) have noted that families provide a general framework for interpreting the appropriateness of aggression. We could hypothesize, therefore, that children of trait verbally aggressive parents grow to expect anger as a normal response to noncompliance. Research tracking expectancy development in children as a function of parents' trait verbal aggressiveness would provide insight into the formation of conflict styles later in life.

Although the role of frustration has been recognized in previous research and theory (Amsel, 1992; Lemerise \& Dodge, 1993; McCord, 1988; Tavris, 1982; Taylor, O'Neal, Langley, \& Butcher, 1990; Wagner, 1966), scholars have treated frustration as a hypothetical construct. In interpersonal contexts, frustration is assumed to mediate blocked efforts at goal attainment and aggressive behavior (Beatty, et al., 1996; deTurck, 1987; Harris, Gergen, \& Lannamann, 1986; Infante, et al., 1989; Infante, et al., 1990; Infante, Trebing, Shepherd, \& Seed, 1984; Lim, 1990). In the present study, 
frustration was measured directly and used in the prediction of anger. Importantly, wide variation in frustration induced through interactions with oppositional children was evidenced in parents' reports. While frustration is commonly assumed to result from thwarted attempts at goal achievement and need expression, why participants in the present study vary in frustration remains unanswered. Recent work by neurobiologists (Depue \& Iocono, 1989; Gray, 1991) indicates that frustration resulting from interrupted goal oriented behavior depends on the attractiveness of the goal. In other words, the more desirable the goal, the greater the frustration when goal directed action fails. Reasoning from this perspective, parents with the highest need to control their children should be most easily frustrated. Given the relationship between parenting style and trait verbal aggressiveness cited earlier, one possible explanation for the variance in frustration could reside in the parents' levels of trait verbal aggressiveness. As a post hoc test, we examined the correlation between parents' trait verbal aggressiveness and frustration, speculating that perhaps parents high in trait verbal aggressiveness might be susceptible to frustration during unsuccessful interactions with their children. However, the observed correlation coefficient $(r=.01)$ did not support that assumption. Further research is needed to investigate both dispositional and situational determinants of parents' frustration in response to interaction with children.

In recent years communication scholars have begun to turn their attention to the emotional dimensions of interpersonal communication (Metts \& Bowers, 1994). However, little research has examined emotion as an outcome of interactions (c.f., Metts \& Cupach, 1989). Working from Infante's (1987a; Infante \& Rancer, 1996) theoretical framework, we investigated parents' anger as a consequence of their trait verbal aggressiveness and frustration experienced during interactions with their children. Our study was productive, providing empirical support for Infante's conceptualization. Further research identifying additional communication-related determinants of emotional experience, both in family and more general interpersonal contexts, is warranted.

\section{REFERENCES}

Amsel, A. (1992). Frustration theory. University Press: Cambridge.

Averill, J. R. (1982). Anger and aggression: An essay on emotion. NY: Springer-Verlag.

Bayer, C. L., \& Cegala, D. J. (1992). Trait verbal aggressiveness and argumentativeness: Relations with parenting style. Western Journal of Communication, 56, 301-310.

Beatty, M. J. (in press). Future directions in trait theory and research. In J. C. McCroskey, J. A. Daly, M. Martin, \& M. J. Beatty (Eds.) Communication and personality: Trait perspectives. New York: Hampton Press.

Beatty, M. J., Burant, P. A., Dobos, J. A., \& Rudd, J. E. (1996). Trait verbal aggressiveness and the appropriateness and effectiveness of fathers' interaction plans. Communication Quarterly, 44, 1-15.

Beatty, M. J., \& Dobos, J. A. (1992a). Adult sons' satisfaction with their relationships with fathers and person-group (father) communication apprehension. Communication Quarterly, 40, 162176.

Beatty, M. J., \& Dobos, J. A. (1992b). Relationship between sons' perceptions of fathers' messages and satisfaction in adult son-father relationships. Southern Communication Journal, 57, 277284. 
Beatty, M. J., \& Dobos, J. A. (1993a). Adult males' perceptions of confirmation and relational partner communication apprehension: Indirect effects of fathers on sons' partners. Communication Quarterly, 41, 66-77.

Beatty, M. J., \& Dobos, J. A. (1993b). Direct and mediated effects of perceived father criticism and sarcasm on females' perceptions of relational partners' disconfirming behavior. Communication Quarterly, 41, 187-197.

Beatty, M. J., \& Dobos, J. A. (1993c). Mediated effects of adult males' perceived confirmation on females' perceptions of relational partners' disconfirming behavior. Southern Communication Journal, 58, 207-214.

Beatty, M. J., Zelley, J. R., Dobos, J. A., \& Rudd, J. E. (1994). Fathers' trait verbal aggressiveness and argumentativeness as predictors of adult sons' perceptions of fathers' sarcasm, criticism, and verbal aggressiveness. Communication Quarterly, 42, 407-415.

Belsky, J., \& Vondra, J. (1993). Lessons from child abuse: The determinants of parenting. In D. Cicchetti \& V. Carlson (Eds.). Child maltreatment: Theory and research on the causes and consequences of child abuse and neglect (pp. 153-202). Cambridge, NY: Cambridge University Press.

Berkowitz, L. (1962). Aggression: A social psychological analysis. New York: McGraw Hill.

Berkowitz, L. (1969). The frustration-aggression hypothesis revisited. In L Berkowitz (Ed.), Roots of aggression (pp. 1-28). New York: Atherton Press.

Berkowitz, L. (1989). The frustration-aggression hypothesis: An examination and reformulation. Psychological Bulletin, 106, 59-73.

Bjorkqvist, K., \& Osterman, K. (1992). Parental influence on children's self-estimated aggressiveness. Aggressive Behavior, 18, 411-423.

Canary, D. J., Spitzberg, B. H., \& Semic, B. A. (in press). The experience and expression of anger in interpersonal settings. In P. A. Andersen \& L. K. Guerrero (Eds.), Communication and emotion: Theory, research, and applications. San Diego, CA: Academic Press.

Chess, S., \& Thomas, A. (1989). Temperament and its functional significance. In S. I. Greenspan \& G. H. Pollack (Eds.), The course of life: Early childhood (Vol. 2, 2nd ed., pp. 163-228). Madison, CT: International Universities Press.

Cohen, J. (1988). Power analysis for the social sciences (2nd ed.). Hillsdale, NJ: Law rence Erlbaum.

Cummings, E. M., Vogel, D., Cummings, J. S., \& El-Sheikh, M. (1989). Children's responses to different forms of expression of anger between adults. Child Development, 60, 1392-1404.

Depue, R. A., \& Iocono, W. G. (1989). Neurobehavioral aspects of affective disorders. Annual Review of Psychology, 40, 457-492.

deTurck, M. A. (1987). When communication fails: Physical aggression as a compliance-gaining strategy. Communication Monographs, 54, 106-112.

El-Sheikh, M., Cummings, M., \& Goetsch V. L. (1989). Coping with adults' angry behavior: Behavioral, physiological, and verbal responses in preschoolers. Developmental Psychology, 25, 490-498.

Epps, J., \& Kendall, P. C. (1995). Hostile attributional bias in adults. Cognitive Therapy and Research, 19, 159-178.

Fatout, M. F. (1990). Aggression: A characteristic of physically abused latency-age children. Child and Adolescent Social Work, 7, 365-376.

Gray, J. A. (1991). The neuropsychology of temperament. In J. Stelau \& A. Angleitner (Eds.), Explorations in temperament (pp. 105-128). New York: Plenum.

Geen, R. G. (1990). Human aggression. Pacific Grove, CA: Brooks/Cole.

Harris, L. M., Gergen, K. J., \& Lannamann, J. W. (1986). Aggression rituals. Communication Monographs, 53, 252-265. 
Infante, D. A. (1987a). Aggressiveness. In J. C. McCroskey \& J. A. Daly (Eds.), Personality and interpersonal communication (pp. 175-192). Newbury Park, CA: Sage.

Infante, D. A. (1987b). Enhancing the prediction of response to a communication situation from communication traits. Communication Quarterly, 35, 308-316.

Infante, D. A. (in press). Corporal punishment of children: A communication theory perspective. In M. A. Straus \& M. D. Donnelly (Eds.), Corporal punishment of children in theoretical perspective. New Haven, CT: Yale University Press.

Infante, D. A., Chandler, T. A., \& Rudd, J. E. (1989). Test of an argumentative skill deficiency model of interpersonal violence. Communication Monographs, 56, 163-177.

Infante, D. A., \& Gordon, W. I. (1985). Superiors' argumentativeness and verbal aggressiveness as predictors of subordinates' satisfaction. Human Communication Research, 12, 117-125.

Infante, D. A., \& Rancer, A. S. (1996). Argumentativeness and verbal aggressiveness: A review of recent theory and research. In B. R. Burleson \& A. W. Kunkel (Eds.), Communication yearbook 19 (pp. 319-352). Thousand Oaks, CA: Sage.

Infante, D. A. Rancer, A. S., \& Womack, D. F. (1997). Building communication theory (3rd ed.). Prospect Heights, IL: Waveland Press.

Infante, D. A., Riddle, B. L., Horvath, C. L., \& Tumlin, S. A. (1992). Verbal aggressiveness: Messages and reasons. Communication Quarterly, 40, 116-126.

Infante, D. A., Sabourin, T. C., Rudd, J. E., \& Shannon, E. A. (1990). Verbal aggression in violent and nonviolent marital disputes. Communication Quarterly, 40, 116-126.

Infante, D. A., Trebing, J. D., Shepherd, P. E., \& Seed, D. E. (1984). The relationship of argumentativeness to verbal aggression. Southern Speech Communication Journal, 50, 67-77.

Infante, D. A., \& Wigley, C. J. (1986). Verbal aggressiveness: An interpersonal model and measure. Communication Monographs, 53, 61-69.

Kerlinger, F. N. \& Pedhazur, E. J. (1973). Multiple regression in behavioral research. New York: Holt, Rinehart, \& Winston.

Lemerise, E. A., \& Dodge, K. A. (1993). The development of anger and hostile interactions. In M. Lewis \& J. M. Haviland (Eds.), Handbook of emotions (pp. 537-546). New York: Guilford Press.

Lim, T. S. (1990). The influence of receivers' resistance on persuaders' verbal aggression. Communication Quarterly, 38, 170-188.

McCord, J. (1988). Parental aggressiveness and physical punishment in long-term perspective. In G. T. Hotaling, D. Finkelhor, J. T. Kirkpatrick, \& M. A. Straus (Eds.), Family abuse and its consequences (pp. 91-98). Newbury Park: Sage.

Metts, S., \& Bowers, J. W. (1994). Emotional and interpersonal communication. In M. L. Knapp \& G. R. Miller (Eds.), Handbook of interpersonal communication (2nd ed., pp. 508 - 541). Thousand Oaks, CA: Sage.

Metts, S., \& Cupach, W. R. (1989). Situational influence on the use of remedial strategies in embarrassing predicaments. Communication Monographs, 56, 151-162.

Rudd, J. E., Beatty, M. J., Vogl-Bauer, S., \& Dobos, J. A. (in press). Trait verbal aggressiveness and the appropriateness and effectiveness of fathers' interaction plans II: Fathers' self-assessments. Communication Quarterly.

Speilberger, C. D., Gorsuch, R. L., \& Luschene, R. E. (1969). STAI manual for state-trait anxiety inventory. Palo Alto: Consulting Psychologists Press.

Stafford, L., \& Bayer, C. L. (1993). Interaction between parents and children. Newbury Park, CA: Sage.

Tavris, C. (1982). Anger. New York: Simon and Schuster.

Taylor, S. L., O'Neal, E. C., Langley, T., \& Butcher, A. H. (1990). Anger arousal, deindividuation, and aggression. Aggressive Behavior, 17, 193-206. 
Vangelisti, A. L. (1993). Communication in the family, the influence of time, relational prototypes, and irrationality. Communication Monographs, 60, 42-54.

Wagner, A. R. (1966). Frustration and punishment. In R. N. Haber (Ed.), Current research in motivation (pp. 157-181). New York: Appleton-Century-Crofts. 
Copyright of Communication Quarterly is the property of Eastern Communication Association and its content may not be copied or emailed to multiple sites or posted to a listserv without the copyright holder's express written permission. However, users may print, download, or email articles for individual use. 